\title{
Three New Pentacyclic Triterpenes and Some Flavonoids from the Fruits of an Indian Ayurvedic Plant Dendrophthoe falcata and Their Estrogen Receptor Binding Activity
}

\author{
Uppuluri Venkata Mallavadhani, ${ }^{*, a}$ Kilambi Narasimhan, ${ }^{a}$ Akella Venkata Subrahmanya Sudhakar, ${ }^{a}$ \\ Anita Mahapatra, ${ }^{a}$ Wenkui Li, ${ }^{b}$ and Richard Bruce van BreEMEN ${ }^{*}, b$ \\ ${ }^{a}$ Traditional and Herbal Drugs Department, Regional Research Laboratory; Bhubaneswar-751 013, India: and \\ ${ }^{b}$ Department of Medicinal Chemistry and Pharmacognosy, University of Illinois College of Pharmacy; 833 South Wood \\ Street, Chicago, IL 60612, U.S.A. Received December 5, 2005; accepted January 31, 2006
}

Extensive chromatographic screening of extracts of the fruits of the Indian Ayurvedic plant, Dendrophthoe falcata, resulted in the isolation of three new triterpenes, $3 \beta$-acetoxy-1 $\beta$-(2-hydroxy-2-propoxy)-11 $\alpha$-hydroxyolean-12-ene (1), $3 \beta$-acetoxy-11 $\alpha$-ethoxy- $\beta$-hydroxy-olean-12-ene (2) and $3 \beta$-acetoxy-1 $\beta$-hydroxy-11 $\alpha$-methoxyolean-12-ene (3) along with nine known compounds, $3 \beta$-acetoxy-1 $\beta, 11 \alpha$-dihydroxy-olean-12-ene (4), $3 \beta$-acetoxy$1 \beta, 11 \alpha$-dihydroxy-urs-12-ene (5), 3 $\beta$-acetoxy-urs-12-ene-11-one (6), $3 \beta$-acetoxy-lup-20(29)-ene (7), 30-nor-lup$3 \beta$-acetoxy-20-one (8), (20S)-3 $\beta$-acetoxy-lupan-29-oic acid (9), kaempferol-3- $O$ - $\alpha$-L-rhamnopyranoside (10), quercetin-3- $O$ - $\alpha$-L-rhamnopyranoside (11), and gallic acid (12). The structures of these compounds were determined using 1D and 2D NMR and high resolution electrospray mass spectrometry. These compounds were assayed for binding to estrogen receptors- $\alpha$ and $\beta$ and kaempferol-3- $O$ - $\alpha$-L-rhamnopyranoside (10) was found to be a ligand for both receptors with greater affinity for $\beta$. The triterpenes $(1-9)$ are reported for the first time in the genus Dendrophthoe and assumes taxonomic significance.

Key words Dendrophthoe falcata; Loranthaceae; triterpene; flavonoid; estrogen receptor

Dendrophthoe falcata (LinN. f.) ETTING. (Syn: Loranthus longiflorus DesR., Loranthus falcatus LinN. f.; Fam. Loranthaceae) is known as 'Vanda' in the Indian Ayurvedic System of Medicine. ${ }^{1)}$ D. falcata is a large bushy parasitic plant that grows on a variety of host plants in deciduous forests throughout India. ${ }^{2}$ The entire plant is medicinally important and is used extensively in traditional medicine as an aphrodisiac, astringent, narcotic, diuretic, and for the relief of asthma, menstrual disorders, and pulmonary tuberculosis. ${ }^{3)}$ It is interesting to note that the medicinal properties of this parasitic plant are greatly influenced by the host plant. For example, when grown on Calotropis gigantea, this parasitic plant is considered useful for improving cognitive function. However, when D. falcata is grown on Tamarindus indicus, it is used to treat impotence, ${ }^{4)}$ and the plant grown on Shorea robusta (Sal tree) is used to treat paralysis by the tribes of the Bihar state of India. ${ }^{5)}$ In addition to its medicinal value, the fruit of $D$. falcata tastes sweet and is consumed as a food. ${ }^{6)}$

Boonsong et $a l^{7)}$ reported the isolation of three cardiac glycosides, viz. strospeside, odoroside $\mathrm{F}$ and neritaloside, from the leaves of $D$. falcata growing on Nerium oleander. Anjeneyulu et al. ${ }^{8)}$ obtained oleanolic acid, its acetate and methyl ester acetate, $\beta$-sitosterol, and stigmasterol from the stems of $D$. falcata growing on Mangifera indica. In addition, Indrani et $a .^{9)}$ reported $(+)$-catechin, leucocyanidin, gallic acid, ellagic acid, and chebulinic acid from the leaves and bark of D. falcata growing on Terminalia tomentosa. In a comparative evaluation of this parasitic plant grown on various host plants, Nair et al. ${ }^{10)}$ reported the accumulation of kaempferol, quercetin, myrecitin, and their glycosides. To the best of our knowledge, the fruits of $D$. falcata have not yet been chemically examined. In view of the above, we have taken up its detailed chemical screening and herein report the isolation of nine taxonomically significant triterpenes from the $n$-hexane extract and three phenolic metabolites from the methanolic extract of the fruits of $D$. falcata growing on Shorea robusta (Sal tree) (Chart 1). Among the triterpenes, three are new compounds $(\mathbf{1}-\mathbf{3})$.

\section{Results and Discussion}

Compound 1 was obtained as a colorless oil. Its molecular formula was determined as $\mathrm{C}_{35} \mathrm{H}_{58} \mathrm{O}_{5}$ by the presence of sodiated mass at $\mathrm{m} / z 581.4157$ (Calcd 581.4182) using HREMS. The presence of an acetoxy group was indicated by the peaks at $1732 \mathrm{~cm}^{-1}$ (IR), $\delta 2.16\left({ }^{1} \mathrm{H}\right)$ and $\delta 20.5$ and $\delta 171.0$ $\left({ }^{13} \mathrm{C}\right.$ ) (Table 1). ${ }^{11)}$ The ${ }^{13} \mathrm{C}$ and DEPT spectra showed the presence of 35 carbons comprising 11 methyl, 8 methylene, 3

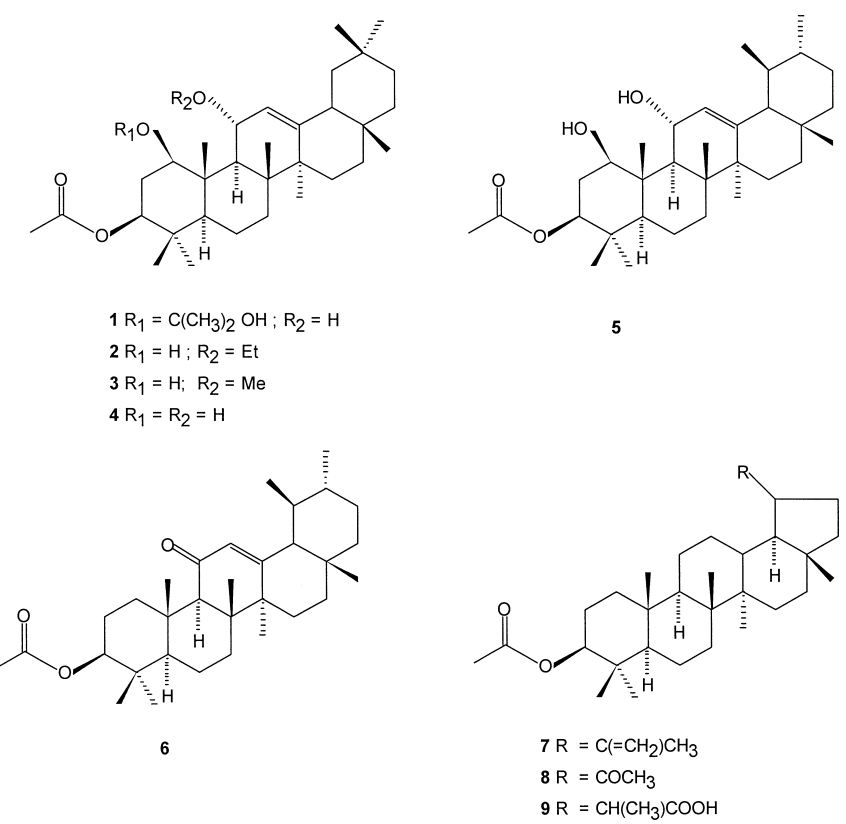

Chart 1. Structures of the Compounds Isolated from D. falcata 


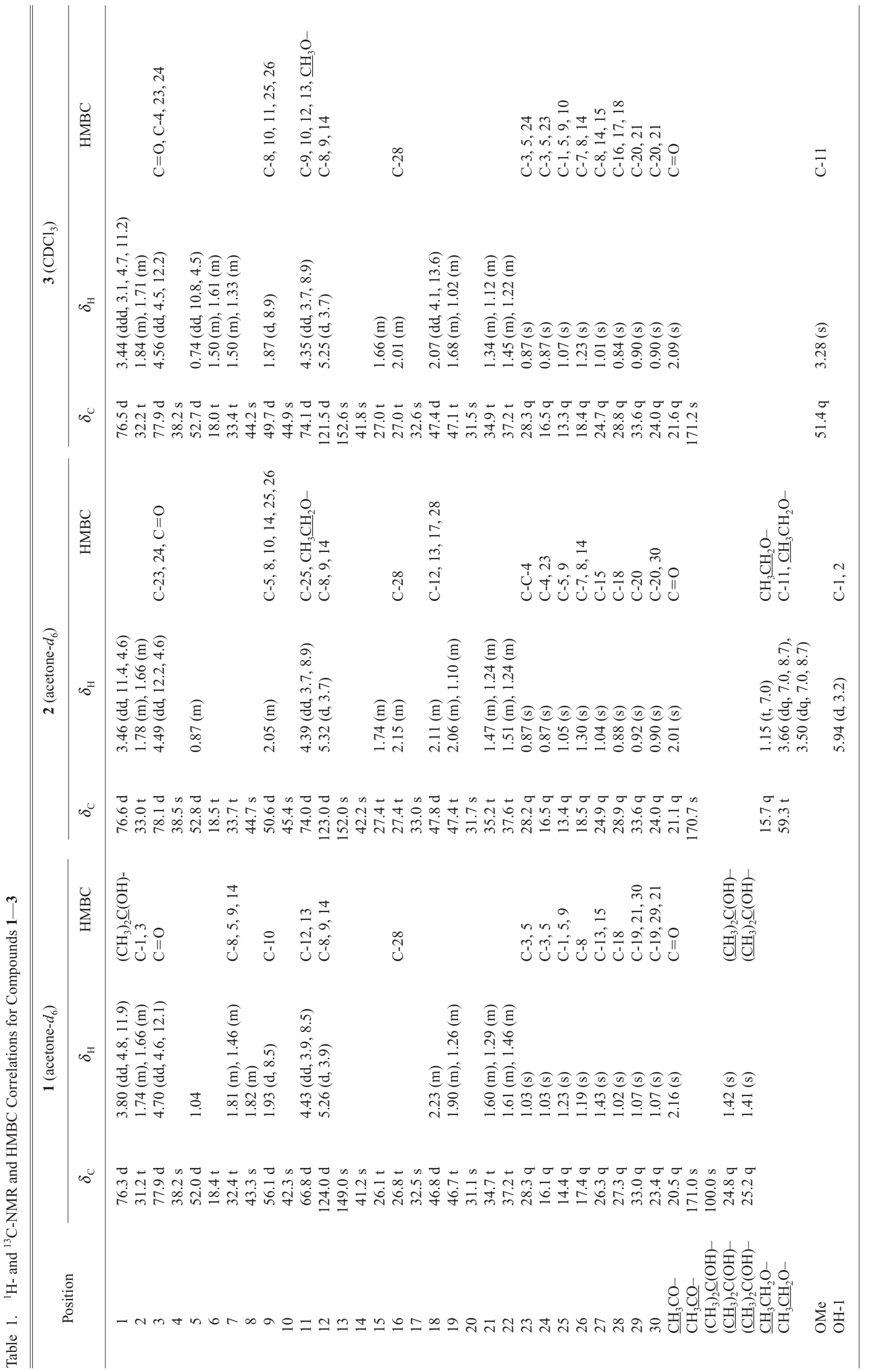


methine, 1 olefinic methine, 3 oxymethine, 7 quaternary carbons (one oxygenated), 1 carboxyl carbon and 1 fully substituted olefinic carbon. Valence bond calculations reveals that there are 7 degrees of unsaturation present in the compound, which, can be accounted for 1 acetoxy carbonyl, 1double bond and 5 ring systems. Detailed $1 \mathrm{D}$ and $2 \mathrm{D}$ NMR $\left({ }^{1} \mathrm{H},{ }^{13} \mathrm{C}\right.$, $\left.{ }^{1} \mathrm{H}-{ }^{1} \mathrm{H}, \mathrm{HMBC}, \mathrm{HMQC}\right)$ analysis of compound $\mathbf{1}$ and comparison with literature data ${ }^{12)}$ suggested that it is an oleanane type pentacyclic triterpene.

The HMQC experiments revealed the presence of an olefinic system between $\mathrm{C}_{12}-\mathrm{C}_{13}$, a $\beta$-acetoxyl at $\mathrm{C}_{3}$, two oxygenated functionalities at $\mathrm{C} 1(\beta)$ and $\mathrm{C} 11(\alpha)$ and a doubly oxygenated quaternary carbon with two methyl groups. ${ }^{13,14)}$ Loss of acetone from sodiated mass $(\mathrm{m} / \mathrm{z} 523)$ and acetone and water from the protonated mass $(\mathrm{m} / \mathrm{z} 483)$ reveals that an isopropoxy substituent is present in compound $\mathbf{1}$.

As compound 1 contains only two hydroxyl groups and the substitutions at all carbons were known except for C-1 and $\mathrm{C}-11$, one hydroxyl group must be located on either $\mathrm{C}-1$ or $\mathrm{C}-11$, and the other must be on an isopropoxy substituent bound to the oleanane skeleton through an ether oxygen. This assignment was supported by the low field chemical shift of the quaternary carbon $(\delta 100.0)$ in the ${ }^{13} \mathrm{C}-\mathrm{NMR}$. Based on the above data, the side substitution was determined to be a 2-hydroxy-2-propoxy group, and its position at C-1 was then confirmed on the basis of HMBC and COSY correlations with its neighbors. In the HMBC spectrum, the quaternary di-oxygenated carbon $(\delta$ 100.0) showed correlations with $\mathrm{H}-1$ ( $\delta$ 3.80) and the methyl group singlets at $\delta$ 1.41 and 1.42 , respectively, which correlated with carbons at $\delta 25.2$ and 24.8, respectively, in the HMQC spectrum (Fig. $1)$. Thus, compound 1 was identified as $3 \beta$-acetoxy- $1 \beta$ - $(2$ hydroxy-2-propoxy)-11 $\alpha$-hydroxy-olean-12-ene.

Compound 2 was isolated as a colorless solid. The IR spectrum indicated the presence of hydroxyl $\left(3346 \mathrm{~cm}^{-1}\right)$ and carbonyl $\left(1721 \mathrm{~cm}^{-1}\right)$ functional groups. The molecular formula of 2 was determined to be $\mathrm{C}_{34} \mathrm{H}_{56} \mathrm{O}_{4}$ using exact mass measurement with high resolution electrospray mass spectrometry. Specifically, the $[\mathrm{M}+\mathrm{Na}]^{+}$ion was detected at $\mathrm{m} / \mathrm{z}$ 551.4075 (Calcd $\mathrm{m} / \mathrm{z}$ 551.4076). Fragment ions were observed in the HR-MS at $m / z 505.3691\left(\mathrm{C}_{32} \mathrm{H}_{50} \mathrm{O}_{3} \mathrm{Na}\right)$, $483.3893\left(\mathrm{C}_{32} \mathrm{H}_{51} \mathrm{O}_{3}\right), 465.3697\left(\mathrm{C}_{32} \mathrm{H}_{49} \mathrm{O}_{3} \mathrm{Na}\right)$, and 423.3659 $\left(\mathrm{C}_{30} \mathrm{H}_{47} \mathrm{O}\right)$, which corresponded to $\left[\mathrm{M}+\mathrm{Na}-\mathrm{C}_{2} \mathrm{H}_{6} \mathrm{O}\right]^{+}$, $\left[\mathrm{MH}-\mathrm{C}_{2} \mathrm{H}_{6} \mathrm{O}\right]^{+},\left[\mathrm{MH}-\mathrm{C}_{2} \mathrm{H}_{6} \mathrm{O}-\mathrm{H}_{2} \mathrm{O}\right]^{+}$, and $\left[\mathrm{MH}-\mathrm{C}_{2} \mathrm{H}_{6} \mathrm{O}-\right.$ $\mathrm{HOAc}^{+}$, respectively. Using a low resolution mass spectrometer, one additional fragment ion was observed at $\mathrm{m} / \mathrm{z}$ 405 (see the Experimental) which probably corresponded to loss of ethanol, acetic acid, and water from the protonated molecule of 2 . The ${ }^{1} \mathrm{H}$ - and ${ }^{13} \mathrm{C}$-NMR spectral data for compound $\mathbf{2}$ were similar to those of $\mathbf{1}$ (Table 1) with the exception that the signals for the 2-hydroxy-2-propoxy group were missing, and signals for an ethoxy group were detected instead. In the ${ }^{1} \mathrm{H}-\mathrm{NMR}$ spectrum signals were detected at $\delta$ $1.15,3.66$ and 3.50 , which corresponded to the carbons at $\delta$ 15.7 and $\delta 59.3$ in the HMQC experiment. In the ${ }^{13} \mathrm{C}-\mathrm{NMR}$ spectrum of compound $\mathbf{2}$, the chemical shifts of the carbons C-9, C-11 and C-12 were observed at $\delta 50.6,74.0$ and $123.0 \mathrm{ppm}$, which shifted $-3.7,+3.8$ and $-1.5 \mathrm{ppm}$, respectively, compared with the corresponding signals of $3 \beta$-acetoxy-1 $\beta, 11 \alpha$-dihydroxy-olean-12-ene. ${ }^{13)}$ This indicated that the ethoxy group was located at $\mathrm{C}-11$. This assignment was
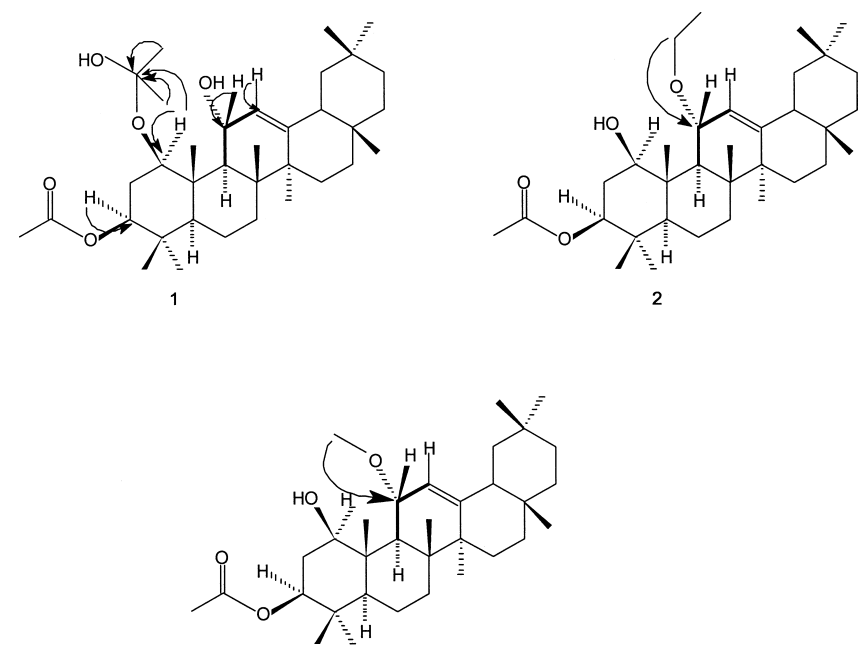

3

Fig. 1. Selected HMBC/HMQC $(\rightarrow)$ and COSY $(-)$ Correlations of Compounds $\mathbf{1}-\mathbf{3}$

also supported by the cross correlation in the HMBC spectrum of the methylene proton peaks at $\delta 3.66$ and $\delta 3.50$ with the $\mathrm{C}-11$ carbon at $\delta 74.0$ and the methyl carbon $(\delta$ 15.7) of the ethoxy group in the HMBC spectrum (Fig. 1). Therefore, the structure of compound $\mathbf{2}$ was determined to be $3 \beta$-acetoxy-11 $\alpha$-ethoxy- $1 \beta$-hydroxy-olean-12-ene.

Compound 3 was isolated as colorless shining needles. The IR spectrum indicated the presence of a hydroxy group $\left(3346 \mathrm{~cm}^{-1}\right)$ and a carbonyl group $\left(1732 \mathrm{~cm}^{-1}\right)$. The molecular formula of 3 was determined to be $\mathrm{C}_{33} \mathrm{H}_{54} \mathrm{O}_{4}$ by HR-MS. Specifically, the $[\mathrm{M}+\mathrm{Na}]^{+}$ion of $\mathbf{3}$ was measured at $\mathrm{m} / \mathrm{z}$ 537.3892 (Calcd $\mathrm{m} / z$ 537.3920). In addition, fragment ions were observed at $m / z 505.3691\left(\mathrm{C}_{32} \mathrm{H}_{50} \mathrm{O}_{3} \mathrm{Na}\right), 483.3803$ $\left(\mathrm{C}_{32} \mathrm{H}_{50} \mathrm{O}_{3}\right), 465.3785\left(\mathrm{C}_{32} \mathrm{H}_{49} \mathrm{O}\right), 423.3659\left(\mathrm{C}_{30} \mathrm{H}_{47} \mathrm{O}\right)$, and $405.3533\left(\mathrm{C}_{30} \mathrm{H}_{45}\right)$. These fragment ions corresponded to $\left[\mathrm{M}+\mathrm{Na}-\mathrm{CH}_{4} \mathrm{O}\right]^{+}, \quad\left[\mathrm{MH}-\mathrm{CH}_{4} \mathrm{O}\right]^{+}, \quad\left[\mathrm{MH}-\mathrm{CH}_{4} \mathrm{O}-\mathrm{H}_{2} \mathrm{O}\right]^{-}$, $\left[\mathrm{MH}-\mathrm{CH}_{4} \mathrm{O}-\mathrm{HOAc}\right]^{+}$, and $\left[\mathrm{MH}-\mathrm{CH}_{4} \mathrm{O}-\mathrm{HOAc}-\mathrm{H}_{2} \mathrm{O}\right]^{+}$, respectively. The ${ }^{1} \mathrm{H}$ - and ${ }^{13} \mathrm{C}$-NMR spectra of compound 3 were similar to those of $\mathbf{2}$ (Table 1) with the exception that the signals for the 11-ethoxy group were absent. Instead, signals for a methoxy group were detected at $\delta 3.28(3 \mathrm{H}, \mathrm{s})$ in the ${ }^{1} \mathrm{H}-\mathrm{NMR}$ spectrum, which corresponded to the carbon at $\delta 51.4$ in the HMQC experiment. In the ${ }^{13} \mathrm{C}$-NMR spectrum of compound 3 the chemical shifts of carbons C-9, C-11 and C-12 were observed at $\delta 49.7,74.1$ and $121.5 \mathrm{ppm}$, respectively, which were shifted $-4.6,+3.9$ and $-3.5 \mathrm{ppm}$ compared to the corresponding signals of $3 \alpha$-acetoxy- $1 \beta, 11 \alpha$ dihydroxy-urs-12-ene and $3 \beta$-acetoxy- $1 \beta, 11 \alpha$-dihydroxyolean-12-ene. ${ }^{13)}$ This indicated that the methoxy group of 3 was located at $\mathrm{C}-11$. This assignment was supported further by the methyl proton signals at $\delta 3.28$ that cross correlated with the carbon at $\mathrm{C}-11$ at $\delta 74.1$ in the HMBC spectrum (Fig. 1). Therefore, compound $\mathbf{3}$ was identified as $3 \beta$-acetoxy- $1 \beta$-hydroxy-11 $\alpha$-methoxy-olean-12-ene.

Compounds $\mathbf{1}-\mathbf{3}$ are new with a rare $\mathrm{C}-1$ and $\mathrm{C}-11$ dioxygenation functionalities. It is noteworthy to mention here that recently five $11 \alpha$-ethoxy, $11 \alpha$-methoxy and $11 \alpha$-hydroperoxy $3 \beta$-acetoxy-urs and olean-12-enes were reported from a plant species, Ficus microcarpa. ${ }^{14)}$ However, these compounds lack the additional oxygen functionality at C-1. 
The other known compounds $3 \beta$-acetoxy- $1 \beta, 11 \alpha$-dihydroxy-olean-12-ene(4), ${ }^{15)} 3 \beta$-acetoxy- $1 \beta, 11 \alpha$-dihydroxy-urs12 -ene $(5),{ }^{13)} 3 \beta$-acetoxy-urs-12-ene-11-one (6), ${ }^{16)} 3 \beta$-acetoxy-lup-20(29)-ene (7), ${ }^{17)} \quad 30$-nor-lup-3 $\beta$-acetoxy-20-one $(\mathbf{8}),{ }^{18)}(20 S)$-3 $\beta$-acetoxy-lupan-29-oic acid (9), ${ }^{12)}$ kaempferol3-O- $\alpha$-L-rhamnopyranoside (10), quercetin-3-O- $\alpha$-L-rhamnopyranoside (11), and gallic acid (12) were also isolated from the fruits of D. falcata (Chart 1) and identified using high resolution mass spectrometry and $1 \mathrm{D}$ and $2 \mathrm{D}$ NMR. ${ }^{1} \mathrm{H},{ }^{13} \mathrm{C}$, DEPT, HMQC, and HMBC NMR analyses were carried out to confirm the structures of these compounds. To the best of our knowledge, this is the first report of the occurrence of the triterpenes $\mathbf{1}-\mathbf{9}$ in the genus Dendrophthoe and assumes taxonomic significance. It is noteworthy to mention here that the host plant, Shorea robusta reported to accumulate pentacyclic triterpenes (resin) $)^{19,20)}$ and phenolics, phenolic acids and flavonoids (heart wood and seeds). ${ }^{21-23)}$ Interestingly all these three classes of compounds were now found in D. falcata fruits.

As the pentacyclic triterpenes and flavonoids were tested earlier for Estrogen Receptor binding activities ${ }^{24)}$ all the isolated compounds were screened for ER binding activities using the recently developed ultra filtration LC-MS methodology. ${ }^{25)}$ Hence, compounds $\mathbf{1} \mathbf{- 1 2}$ were assayed for binding to estrogen receptor- $\alpha$ (ER- $\alpha$ ) and ER- $\beta$ based on competitive binding with radio labeled estradiol. ${ }^{26)}$ Among these compounds, kaempferol-3-O- $\alpha$-L-rhamnopyranoside (10), was found to be a weak ligand for the estrogen receptor in vitro with a greater affinity for estrogen receptor- $\beta$.

\section{Experimental}

General Melting points were determined using a standard capillary melting point apparatus and are uncorrected. The optical rotations were measured using a JASCO (Tokyo, Japan) P-1020 digital polarimeter, and IR spectra were recorded on a JASCO FTIR-5300 spectrometer. NMR spectra were measured using Bruker (Rheinstetten, Germany) Advance 360 and DPX-300 spectrometers. The chemical shift values are reported in parts per million ( $\mathrm{ppm}$ ) relative to the internal standard TMS, and the coupling constants are in $\mathrm{Hz}$ (in parentheses). For the NMR spectra, multiplicities were determined by DEPT experiments (DEPT 90 and DEPT 135). Positive ion electrospray low and high resolution mass spectra were obtained using a Micromass (Manchester, U.K.) Quattro II triple quadruple spectrometer and a Q-TOF-2 hybrid mass spectrometer, respectively. Samples dissolved in methanol/water/formic acid $(50: 49: 1)$ were infused into the mass spectrometer at $20 \mu \mathrm{l} / \mathrm{min}$ at an ion source temperature of $140^{\circ} \mathrm{C}$.

Plant Material The fruits of D. falcata growing on Shorea robusta $(\mathrm{Sal}$ tree) were collected from the Baliguda forest $\left(20^{\circ} 07^{\prime} \mathrm{N}, 83^{\circ} 05^{\prime} \mathrm{E}\right)$ of Orissa India, during April, 1999. Voucher specimens (010499) were deposited at the Traditional and Herbal Drugs Department, Regional Research Laboratory, Bhubaneswar, India.

Extraction and Isolation The shade dried and powdered fruits $(1.0 \mathrm{~kg})$ of D. falcata were extracted successively with $n$-hexane $(31 \times 12)$ and then methanol $(31 \times 12)$ using a soxhlet extractor. The solvent was removed under vacuum to yield the respective $n$-hexane $(190 \mathrm{~g})$ and methanol $(110 \mathrm{~g})$ extracts. A portion of the $n$-hexane extract $(100 \mathrm{~g})$ was chromatographed over a silica gel column $(100-200$ mesh, $95 \times 7.5 \mathrm{~cm})$ with a solvent gradient from $n$-hexane to ethyl acetate to yield six major fractions: A ( $n$-hexane/EtOAc, $97: 3)$, B ( $n$-hexane/EtOAc, $92.5: 7.5), \mathrm{C}(n$-hexane/EtOAc, $80: 20), \mathrm{D}$ and $\mathrm{E}(n$-hexane/EtOAc, $65: 35)$, and F ( $n$-hexane/EtOAc, $1: 1)$.

Fractions D $(0.3 \mathrm{~g})$ and $\mathrm{F}(6.8 \mathrm{~g})$ on repetitive column chromatographic purifications afforded compound $\mathbf{1}(4 \mathrm{mg})$ and compounds $2(5 \mathrm{mg}), 3$ $(12 \mathrm{mg}), 4(7 \mathrm{mg})$ and $5(22 \mathrm{mg})$ respectively. Similarly, fractions B $(1.2 \mathrm{~g})$, $\mathrm{A}(7.6 \mathrm{~g})$ and $\mathrm{C}(2.8 \mathrm{~g})$ were also individually purified to yield compound 6 $(16 \mathrm{mg}), 7(190 \mathrm{mg})$ and $8(42 \mathrm{mg})$ respectively. However, fraction E $(0.65 \mathrm{~g})$ on re-crystallization afforded compound $\mathbf{9}(150 \mathrm{mg})$.

The methanol extract $(85 \mathrm{~g})$ was rechromatographed on a smaller silica gel column $(85 \times 6 \mathrm{~cm})$ using a gradient solvent system from $100 \%$ chloroform to $100 \%$ methanol. Three known phenolic compounds were isolated, $\mathbf{1 0}(30 \mathrm{mg}), \mathbf{1 1}(120 \mathrm{mg})$ and $\mathbf{1 2}(99 \mathrm{mg})$.

$3 \beta$-Acetoxy-1 $\beta$-(2-hydroxy-2-propoxy)-11 $\alpha$-hydroxy-olean-12-ene $\quad$ (1): Colorless oil. $[\alpha]_{\mathrm{D}}+301^{\circ}\left(c=0.1, \mathrm{CHCl}_{3}\right)$. IR (neat, $\left.\mathrm{cm}^{-1}\right) \lambda_{\max }: 3325$ $(-\mathrm{OH}), 1732\left(\mathrm{C}=\mathrm{O}\right.$, acetate), $1244(\mathrm{C}-\mathrm{O}$, acetate $), 1078$ (ether). ${ }^{1} \mathrm{H}-$ and ${ }^{13} \mathrm{C}$-NMR, see Table 1. Positive ion electrospray MS $\mathrm{m} / \mathrm{z}$ (\%): 581.4157 $[\mathrm{M}+\mathrm{Na}]^{+}(\mathrm{Calcd} 581.4182,10), 563.4050\left[\mathrm{M}+\mathrm{Na}-\mathrm{H}_{2} \mathrm{O}\right]^{+}(20), 541.4276$ $\left[\mathrm{MH}-\mathrm{H}_{2} \mathrm{O}\right]^{+}(10), 523.3738[\mathrm{M}+\mathrm{Na}-\text { acetone }]^{+}(5), 483.3893[\mathrm{MH}-$ acetone $\left.-\mathrm{H}_{2} \mathrm{O}\right]^{+}(100), 465.3697\left[\mathrm{MH}-\text { acetone }-2 \mathrm{H}_{2} \mathrm{O}\right]^{+}(30)$.

$3 \beta$-Acetoxy-11 $\alpha$-ethoxy-1 $\beta$-hydroxy-olean-12-ene (2): Colorless solid. mp $182-184^{\circ} \mathrm{C} .[\alpha]_{\mathrm{D}}+224^{\circ}\left(c=0.1, \mathrm{CHCl}_{3}\right)$. IR $\left(\mathrm{KBr}, \mathrm{cm}^{-1}\right) \lambda_{\max }: 3346$ $(-\mathrm{OH}), 1721\left(\mathrm{C}=\mathrm{O}\right.$, acetate), $1248\left(\mathrm{C}-\mathrm{O}\right.$, acetate), 1061 (ether). The ${ }^{1} \mathrm{H}-$ and ${ }^{13} \mathrm{C}-\mathrm{NMR}$, see Table 1. Positive ion electrospray MS $\mathrm{m} / \mathrm{z}$ (\%): 551.4075 $[\mathrm{M}+\mathrm{Na}]^{+}(20), 505.3691\left[\mathrm{M}+\mathrm{Na}-\mathrm{EtOH}^{+}(5), 483.3893[\mathrm{MH}-\mathrm{EtOH}]^{+}\right.$ $(100), 465.3697 \quad\left[\mathrm{MH}-\mathrm{EtOH}-\mathrm{H}_{2} \mathrm{O}\right]^{+} \quad(15), 423.3659 \quad[\mathrm{MH}-\mathrm{EtOH}-$ $\mathrm{HOAc}^{+}(45)$.

$3 \beta$-Acetoxy- $1 \beta$-hydroxy- $11 \alpha$-methoxy-olean-12-ene (3): Colorless shining needles. $\mathrm{mp} 228^{\circ} \mathrm{C} .[\alpha]_{\mathrm{D}}+212.7^{\circ}\left(c=0.25, \mathrm{CHCl}_{3}\right)$. IR $\left(\mathrm{KBr}, \mathrm{cm}^{-1}\right)$ $\lambda_{\max }: 3346(-\mathrm{OH}), 1732(\mathrm{C}=\mathrm{O}$, acetate $), 1248(\mathrm{C}-\mathrm{O}$, acetate), 1049 (ether). ${ }^{1} \mathrm{H}-$ and ${ }^{13} \mathrm{C}-\mathrm{NMR}$, see Table 1 . Positive ion electrospray MS $\mathrm{m} / \mathrm{z}(\%)$ $537.3892[\mathrm{M}+\mathrm{Na}]^{-}(10), 505.3691[\mathrm{M}+\mathrm{Na}-\mathrm{MeOH}]^{+}(15), 483.3803$ $[\mathrm{MH}-\mathrm{MeOH}]^{+}(100), 465.3785\left[\mathrm{MH}-\mathrm{MeOH}-\mathrm{H}_{2} \mathrm{O}\right]^{+}(20), 423.3659$ $[\mathrm{MH}-\mathrm{MeOH}-\mathrm{HOAc}]^{+} \quad(45), \quad 405.3533 \quad\left[\mathrm{MH}-\mathrm{MeOH}-\mathrm{HOAc}-\mathrm{H}_{2} \mathrm{O}\right]^{+}$ (15).

Acknowledgements We thank Prof. V. N. Misra, Director, RRL, Bhubaneswar for permission to publish this paper, the Head of the Forest and Marine Products Department for encouragement, and Sri. K. S. Murthy, Central Ayurvedic Research Institute, Bhubaneswar, for help in procuring the plant material. We are grateful to the CSIR, New Delhi, for awarding a Senior Research fellowship to KN, and to the Research Resources Center of the University of Illinois at Chicago for the use of the mass spectrometers and NMR instruments.

\section{References and Notes}

1) The Controller of the Publications, "The Ayurvedic Formulary of India," Part-II, Indian Government Publication, New Delhi, India, 2000, p. 338

2) Asolkar L. V., Kakkar K. K., Chakre O. J., "Glossary of Indian Medicinal Plants with Active Principles," Part-I, CSIR, New Delhi, India 1992 , p. 265

3) Sastry B. N., "The Wealth of India (Raw Materials)," Vol. III, CSIR, New Delhi, India, 1952, p. 34.

4) Warrier P. K., Nambiar V. P. K., Ramankutty C., "Indian Medicinal Plants a Compendium of 500 Species," Vol. II, Orient Longman, India, 1993, pp. 316-317.

5) Jain S. K., "Contributions to Indian Ethanobotany," 3rd ed., Scientific Publishers, Jodhpur, India, 1997, p. 96.

6) Unpublished Ethanobotanical claim.

7) Boonsong C., Wright S. E., Aust. J. Chem., 14, 449-451 (1961)

8) Anjeneyulu A. S. R., Row L. R., Reddy D. S., Curr. Sci., 46, 850-851 (1977).

9) Indrani N., Rao V. S. S., Balasubramanian K., Reddy K. K., Ramayya T. V., Leather Sci., 27, $438-439$ (1980) [Chem. Abstr., 95, 58107t (1981)].

10) Nair A. G. R., Krishnakumary P., Ind. J. Chem., 29B, 584-585 (1990).

11) Chiang Y. M., Kuo Y. H., J. Nat. Prod., 64, 436- 439 (2001).

12) Ahmad V. U., Rahman A. U., "Hand Book of Natural Products Data," Vol. 2, Elsevier, Amsterdam, Netherlands, 1994.

13) Topcu G., Ulubelen A., J. Nat. Prod., 62, 1605-1608 (1999).

14) Kuo Y. H., Chiang Y. M., Chem. Pharm. Bull., 48, 593-596 (2000).

15) Gonzalez A. G., Ferro E. A., Ravelo A. G., Phytochemistry, 26, 2785-2788 (1987).

16) Zhang Q. Y., Zhao Y. Y., Cheng T. M., Cui Y. X., Liu X. H., J. Asian Nat. Prod. Res., 2, 81-86 (2000).

17) Flagg M. L., Valcic S., Montenegro G., Gomez M., Timmermann B. N., Phytochemistry, 52, 1345-1350 (1999).

18) Koul S., Razdan T. K., Andotra C. S., Kalla A. K., Koul A. K., Taneja S. C., Dhar K. L., Phytochemistry, 53, 305-309 (2000).

19) Hota R. K., Bapuji M., Phytochemistry, 32, 466- 468 (1993).

20) Purushothaman K. K., Saraswathy A., Sasikala E., Indian Drugs, 26 , 146-150 (1988)

21) Rastogi R. P., Mehrotra B. N., "Compendium of Indian Medicinal Plants," Vol. 2, CDRI and Publications \& Information Directorate, 
New Delhi, 1993, p. 625.

22) Prakash E. O., Rao J. T., Fitoterapia, 70, 539-541 (1999).

23) Jain A., Bhartiya H. P., Vishwakarma A. N., Phytochemistry, 21, 957-958 (1982)

24) Onorato J., Henion J. D., Anal. Chem., 73, 4704 4710 (2001).
25) Liu J., Burdette J. E., Xu H., Gu C., van Breemen R. B., Bhat K. P. L., Booth N., Constantinou A. I., Pezzuto J. M., Fong H. H. S., Farnsworth N. R., Bolton J. L., J. Agric. Food Chem., 49, 2472-2479 (2001).

26) Obourn J. D., Koszewski N. J., Nortides A. C., Biochemistry, 32 $6229-6236(1993)$ 